\title{
Wild birds as reservoirs of multidrug-resistant enterobacteria in Mulungu, Brazil
}

Antonio Jackson Forte Beleza*1 (Corresponding author: jacksonfortemv@gmail.com); William Cardoso Maciel ${ }^{1}$ (william.maciel@uol.com.br); Arianne Silva Carreira ${ }^{1}$ (ariannecarreira@hotmail.com); Adson Ribeiro Marques ${ }^{1}$ (adsonribeiromarques@gmail.com); Carlos Henrique Guedes Nogueira ${ }^{1}$ (chgn4567@gmail.com); Neilton Monteiro Pascoal Filho' (m.neilton@yahoo.com.br);

Bruno Pessoa Lima ${ }^{1}$ (bplima2002@yahoo.com.br); Isaac Neto Goes da Silva ${ }^{1}$ (isaac.neto@uece.br); Ruben Horn Vasconcelos2 (rubenhorn@hotmail.com); Leandro Rodrigues Ribeiro $^{3}$ (leandrorvet@gmail.com); Régis Siqueira de Castro Teixeira ${ }^{1}$ (regis_siqueira_teixeira@yahoo.com.br)

\author{
${ }^{1}$ Affiliation: Postgraduate Program in Veterinary Science, Veterinary Faculty, State \\ University of Ceará. Av. Dr. Silas Munguba, 1700, Campus do Itaperi. Zip Code: \\ 60740-903 Fortaleza, Ceará, Brasil \\ ${ }^{2}$ Affiliation: Laboratory of Animal Anatomy and Pathology, Federal University of the \\ Agreste of Pernambuco. Av. Bom Pastor, s/n. ${ }^{\circ}$ - Boa Vista, Garanhuns - PE, 55292-270 \\ ${ }^{3}$ Affiliation: Fazenda Haras Claro, Rod Br 020 Km 381 Bom Princípio, 61600900 \\ Caucaia, CE \\ Corresponding author \\ E-mail:jacksonfortemv@gmail.com
}

\section{ABSTRACT}

Caatinga is a biome unique to Brazil that is degraded by anthropogenic actions, which lead to the loss of biodiversity putting many species at risk of extinction. The Ceará State is located in the Caatinga and has a rich avifauna comprised of 433 species including 13 species that are threatened with extinction, which are found in the Baturité Massif. The aim of this study was to investigate the frequency and diversity of enterobacteria in wild birds and to determine their susceptibility to antimicrobials. Cloacal swab samples were collected from 50 individuals of 28 different species, including the Ceara Gnatheter (Conopophaga cearae) and Red-necked Tanager (Tangara cyanocephala cearensis), which are classified as vulnerable (VU) by the Brazilian Ministry of the Environment. A total of 55 isolates belonging to 14 different species of Enterobacteriaceae were identified. Among these, Pantoea agglomerans and Escherichia coli were the most prevalent species with isolation rates of $36 \%$ and $26 \%$, respectively. The highest rate of antimicrobial resistance found was to ampicillin (41.8\%), followed by nalidixic Acid (36.3\%) and amoxicillin associated with clavulanic 
acid (32.7\%). The drugs with the best efficacy were tobramycin (96.4\%), ciprofloxacin $(92.6 \%)$ and tetracycline (90.9\%). Multidrug resistance was observed in $23.5 \%$ of the analyzed strains. This research provides important information about the composition of the cloacal microbiota of wild birds in Mulungu, Brazil, as well as their health status. In addition, these results demonstrate that they harbor multidrug-resistant strains of Enterobacteriaceae.

\section{Introduction}

It is estimated that the Caatinga biome is home to 548 species of birds, which are distributed in 74 families and represent $28.6 \%$ of the total number of species recorded in Brazil [1]. The Ceará State, Brazil, is located in this biome, which has dry landscapes as its main geographic feature. Nonetheless, it presents other striking phytophysiognomies, such as coastal forests, often associated with extensive mangroves, Cerrado fragments, in addition to remnants of Atlantic Forest and Forest Amazon embedded in the semiarid zone $[2,3,4,5]$, as occurs in the enclaves of humid forest occurring in the Baturité Massif [6]. The Baturité Massif has been under strong anthropogenic pressure and since its original occupation it has suffered severe environmental degradation caused by deforestation, fires, introduction of exotic species, dismemberment of sites, predatory hunting and growth of urban centers, which have been important factors for the alteration of the local biota [7]. In addition, it is home to 13 bird species that are classified as threatened in the Red List of the Brazilian Ministry of the Environment [8]. Therefore, the Baturité Massif is a priority area for avian conservation in Northeastern Brazil [9].

The environmental degradation can promote notable negative consequences on wildlife [10]. Environmental pollution is one of the anthropogenic actions that puts the conservation of avifauna at risk, mainly on aspects related to the dissemination of pathogens that are important for animal and public health, such as Salmonella and other enteropathogens $[11,12]$. Furthermore, free-ranging birds may come into contact with residues of antibiotics or resistant microorganisms when exposed to contaminants in the environment in which they live $[13,14,15]$. This may affect the health of birds, considering that factors such as ingestion of antibiotics and infection by pathogenic organisms may alter the microbiota of birds $[16,17,18]$.

Several studies with free-living birds have shown that they may carry strains of bacteria from the Enterobacteriaceae family with resistance to multiple antimicrobials 
$[19,20,21]$. Over several decades, antimicrobial resistance has become a global clinical and public health threat against the effective treatment of common infections caused by resistant pathogens, resulting in treatment failure and increased mortality [22]. The development of bacterial resistance can be explained by the natural evolution of microorganisms. However, the widespread and misuse of antibacterial agents in humans and animals has accelerated this process [22]. In recent years, substantial evidence has been provided linking the high presence of antimicrobial-resistant bacteria in the environment with anthropogenic sources $[23,24]$. In this context, there is a growing interest in researches involving the environment, including wildlife, in order to better understand the effects of pollution and antimicrobial resistance derived from anthropogenic impacts in ecosystems [25, 26, 27].

Anthropogenic effects on wildlife are poorly investigated, and the extent to which animal populations contribute to the spread of antibiotic resistance is still unknown. Therefore, considering that there are few studies investigating the contact that free-living birds have with multidrug-resistant enterobacteria in the Ceará State, which are generally limited to a few species, greater elucidation is needed [28, 29, 15, 30].

Hence, this study aimed to investigate the presence of enterobacteria in cloacal swab samples of wild birds captured in the city of Mulungu, Ceará, Brazil, and to determine the phenotypic profile of antimicrobial sensitivity of the isolates.

\section{Material and methods}

\section{Characterization of the Study Area}

This study was authorized by the Brazilian Institute for the Environment and Renewable Natural Resources (IBAMA) with SISBIO protocol number 31847-6 and approved by the Ethics Committee for the Use of Animals of the State University of Ceará (Protocol number 4832011/2014).

The study was carried out in the city of Mulungu, Ceará, which is located in the Baturité Massif that contains 16 cities: Aratuba, Baturité, Canindé, Capistrano, Charity, Guaramiranga, Mulungu, Redenção, Pacoti, Palmacia, Acarape, Barreira, Aracoiaba, Guaiúba, Maranguape and Itapiúna. Within the region known as the Baturité Massif, an Environmental Protection Area (APA) is located at an approximate distance of 120 kilometers from the state capital, Fortaleza. This APA presents its highest peak at 1115 meters in altitude and is composed by tropical pluvial subdeciduous forest and pluvionebular subevergreen forest (average annual temperatures of $24^{\circ}$ to $26^{\circ}$ with average 
annual rainfall of 1,737.5 millimeters and with hot sub-humid and humid tropical conditions) with trees up to 30 meters high, river springs and waterfalls. This region show a marked contrast to the surrounding semiarid backwoods (sertão) in the middle of a hot dry region. It has high anthropogenic activity, such as agriculture, livestock and urban growth, and presents mostly altered vegetation [31, 32, 33].

Sample collection

The capture of birds was conducted for 3 months (october, november and december 2019) with the aid of 4 mist nets (Ecotone Mist nets - 1030/12-nailon; length: $12 \mathrm{~cm}$; height: 3.2m; mesh: 30x30cm; denier: 110/2; 4 bags, fixed with rods at the ends).

The nets were placed $20 \mathrm{~cm}$ above the ground in linear transects in the forest. These were opened at dawn and closed at dusk (7:00 am to 5:00 pm) and were checked every 20 minutes to remove the captured birds.

The species were identified according to the Avis Brasilis field guide [34] and by consulting the list of birds in Brazil made available by the Brazilian Committee for Ornithological Records - CBRO [35].

Biological samples were obtained using sterile cloacal swabs, which were stored in Stuart medium at room temperature, transported and sent within 48 hours to the Ornithological Studies Laboratory, State University of Ceará (LABEO/UECE) for further microbiological processing. After sampling, individuals were marked by clipping a secondary feather from the right wing before being released back to the wild. Microbiological procedure

Once at the Ornithological Studies Laboratory (LABEO), samples were transferred from Stuart media to $5 \mathrm{~mL}$ of $1 \%$ Peptone Water (Kasvi ${ }^{\circledR}$ ) and were cultured. The incubation conditions were standardized at $37^{\circ} \mathrm{C} / 24 \mathrm{~h}$ for all the steps of the microbiological procedure. Aliquots of $0.5 \mathrm{~mL}$ were collected from the peptone water samples and transferred to tubes containing Brain-Heart Infusion (Kasvi®) (BHI) and Selenite-Cystine (Kasvi ${ }^{\circledR}$ ) (SC) enrichment broths. In addition, aliquots of $0.05 \mathrm{~mL}$ were collected and transferred to Rappaport-Vassiliadis broth (Kasvi®) (RP). After incubation, a loopful was collected from each broth and streaked on plates containing Brilliant Green agar (Himedia ${ }^{\circledR}$ ), Salmonella-Shigella agar (Himedia ${ }^{\circledR}$ ) and MacConkey agar (Kasvi®), following incubation. Different colonies were collected from each plate and were inoculated into tubes containing Triple Sugar Iron Agar 
140 (Kasvi®). To identify the enterobacteria, biochemical tests were used, including SIM

141 Medium (Himedia $\left.{ }^{\circledR}\right)$, lysine-decarboxylase (LIA) (Kasvi®), ornithine-decarboxylase

142 (Himedia $\left.{ }^{\circledR}\right)$, methyl red (VM), Voges-Proskauer (VP) (Himedia ${ }^{\circledR}$ ), Urea (Dynamic

143 Formula ${ }^{\circledR}$ ), Simmons Citrate Agar (Himedia $\left.{ }^{\circledR}\right)$, Arginine Decarboxylase (Exodus

144 Cientifica $\left.{ }^{\circledR}\right)$, Malonate Broth $\left(\operatorname{Himedia}^{\circledR}\right)$ ), Lactose (Merck $\left.{ }^{\circledR}\right)$, Sucrose (Dinâmica ${ }^{\circledR}$ ),

145 Mannitol (Dinâmica $\left.{ }^{\circledR}\right)$, Arabinose (Dinâmica $\left.{ }^{\circledR}\right)$, Raffinose (Dinâmica ${ }^{\circledR}$ ), Rhamnose

146 (Dinâmica $\left.{ }^{\circledR}\right)$, Sucrose (Dinâmica $\left.{ }^{\circledR}\right)$, Dulcitol (Dynâmica $\left.{ }^{\circledR}{ }^{\circledR}\right)$, Adonitol (Dinâmica $\left.{ }^{\circledR}\right)$,

147 Inositol (Sigma $\left.{ }^{\circledR}\right)$ and Sorbitol (Sigma $\left.{ }^{\circledR}\right)[36]$.

148 Antimicrobial susceptibility profile

149 The isolates were submitted to anticrobial susceptibility test using the Kirby-

150 Bauer disk diffusion technique [37], and the inhibition zones were compared to the

151 standards established by the Clinical and Laboratory Standards Institute-CLSI [38].

152 Eleven antimicrobials of 7 pharmacological classes were tested: Quinolones (Nalidixic

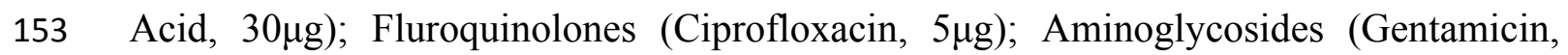

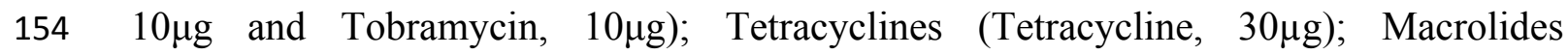

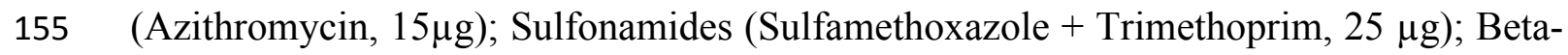

156 lactams (Penicillin: Ampicillin, $10 \mu \mathrm{g}$ and Amoxicillin + Clavulanic Acid $10 \mu \mathrm{g}$,

157 Cephalosporins: Ceftriaxone, $30 \mu \mathrm{g}$ and Carbapenems: Meropenem 10 $\mu \mathrm{g}$ ); (All

158 antimicrobials from Oxoid Ltd., Cambridge, UK confirm brand*). Isolates that

159 expressed resistance or intermediate phenotypes were interpreted as resistant. Bacteria

160 were considered resistant to multiple drugs (RMD) when resistance occurred to at least

161 three classes of antibiotics [39]. The Escherichia coli ATCC 25922 strain was used as a

162 control sample. To perform the test, isolates were cultured in tubes containing $5 \mathrm{~mL}$ of

163 Brain-heart Infusion broth (BHI), and placed in bacteriological incubator for 24 hours at

$16437^{\circ} \mathrm{C}$. Subsequently, aliquots of the broth were seeded onto MacConkey agar plates and

165 again incubated. Afterwards, two to three colonies were selected and placed in $5 \mathrm{~mL}$

166 tubes of saline solution. Then, a swab was moistened in the turbid saline solution

167 (which contained a turbidity of 0.5 according to the Mcfarland Nephelometric scale)

168 and streaked on the surface of a plate containing Mueller-Hinton agar (Kasvi ${ }^{\circledR}$ ), to

169 which antimicrobial discs were placed. After the plates were incubated at $37^{\circ} \mathrm{C}$ for $24 \mathrm{~h}$,

170 the inhibition zones were measured and results were interpreted as sensitive or resistant. 
173 families were captured (Table 1). The most frequent species was Pectoral Sparrow

174 (Arremon taciturnus), in a total of 5 individuals, followed by the occurrence of Yellow-

175 bellied Elaenia (Elaenia flavogaster) and Ruddy Ground-Dove (Columbina talpacoti),

176 both with 4 individuals. Two rare species classified as vulnerable (VU) were also

177 collected, which were the Ceara Gnateater (Conopophaga cearae) and the Red-necked

178 Tanager (Tangara cyanocephala cearensis) [8].

Table 1. List of bird species captured in the city of Mulungu, Ceará, Brazil

\begin{tabular}{|c|c|c|}
\hline Family & Common and scientific name & $\begin{array}{c}\text { Captured } \\
\text { animals }\end{array}$ \\
\hline \multirow[t]{6}{*}{ Thraupidae } & $\begin{array}{l}\text { Red-necked Tanager (Tangara cyanocephala } \\
\text { cearensis) }\end{array}$ & 2 \\
\hline & Burnished-buff Tanager (Stilpnia cayana) & 1 \\
\hline & Bananaquit (Coereba flaveola) & 2 \\
\hline & Palm Tanager (Thraupis palmarum) & 3 \\
\hline & Guira Tanager (Hemithraupis guira) & 1 \\
\hline & Orange-headed Tanager (Thlypopsis sordida) & 1 \\
\hline \multirow[t]{4}{*}{ Tyrannidae } & Gray Elaenia (Myiopagis caniceps) & 2 \\
\hline & Mouse-colored Tyrannulet (Phaeomyias murina) & 1 \\
\hline & Short-crested Flycatcher (Myiarchus ferox) & 1 \\
\hline & Yellow-bellied Elaenia (Elaenia flavogaster) & 4 \\
\hline \multirow[t]{2}{*}{ Columbidae } & Gray-fronted Dove (Leptotila rufaxilla) & 2 \\
\hline & Ruddy Ground-Dove (Columbina talpacoti) & 4 \\
\hline \multirow[t]{3}{*}{ Trochilidae } & $\begin{array}{l}\text { Ruby-topaz } \quad \text { Hummingbird } \quad \text { (Chrysolampis } \\
\text { mosquitus) }\end{array}$ & 1 \\
\hline & Fork-tailed Woodnymph (Thalurania furcata) & 2 \\
\hline & Rufous-breasted Hermit (Glaucis hirsutus) & 3 \\
\hline Passerellidae & Pectoral Sparrow (Arremon taciturnus) & 5 \\
\hline \multirow[t]{4}{*}{ Dendrocolaptidae } & Straight-billed Woodcreeper (Dendroplex picus) & 2 \\
\hline & $\begin{array}{lll}\begin{array}{l}\text { Planalto } \\
\text { platyrostris) }\end{array} & \text { Woodcreeper } & \text { (Dendrocolaptes }\end{array}$ & 1 \\
\hline & $\begin{array}{l}\text { Lafresnaye's Woodcreeper (Xiphorhynchus } \\
\text { guttatoides eytoni) }\end{array}$ & 1 \\
\hline & $\begin{array}{l}\text { Red-billed Scythebill } \quad \text { (Campylorhamphus } \\
\text { trochilirostris) }\end{array}$ & 1 \\
\hline \multirow[t]{2}{*}{ Turdidae } & Pale-breasted Thrush (Turdus leucomelas) & 1 \\
\hline & Rufous-bellied Thrush (Turdus rufiventris) & 2 \\
\hline Furnariidae & Pale-legged Hornero (Furnarius leucopus) & 2 \\
\hline Picidae & $\begin{array}{lll}\begin{array}{l}\text { Green-barred } \\
\text { melanochloros) }\end{array} & \text { Woodpecker } & \text { (Colaptes } \\
\end{array}$ & 1 \\
\hline
\end{tabular}


Conopophagidae

Icteridae

Ceara Gnateater (Conopophaga cearae) 1

Thamnophilidae Variable Oriole (Icterus pyrrhopterus) 1

Hirundinidae $\quad$ Southern Rough-winged Swallow (Stelgidopteryx

Great Antshrike (Taraba major) 1 ruficollis)

\begin{tabular}{lll}
\hline Total 28 & 50 \\
\hline
\end{tabular}

A total of 55 strains distributed in 14 different bacterial species were detected in the analyzed samples. The prevalence of positive birds for at least one bacterial species was 52.0\%. Pantoea agglomerans and Escherichia coli were the most prevalent ones, occurring in $36.0 \%(18 / 50)$ and $26 \%(13 / 50)$ of the investigated birds. Serratia rubidaea was the third most isolated bacterial species, followed by Hafnia alvei, which presentedisolation rates of $14.0 \%(7 / 50)$ and $10.0 \%(5 / 50)$, respectively (Table 2$)$. 
Table 2- Absolute and relative frequencies of enterobacteria per bird family in cloacal samples of wild birds captured from October to December 2019 in the city of Mulungu, Ceará, Brazil

\begin{tabular}{|c|c|c|c|c|c|c|c|c|c|c|c|c|c|c|}
\hline \multirow{2}{*}{$\begin{array}{c}\text { Isolated } \\
\text { Enterobacteriaceae }\end{array}$} & \multirow{2}{*}{$\begin{array}{c}\text { Total } \\
\text { number } \\
\text { of birds } \\
(\mathrm{n}=50)\end{array}$} & \multicolumn{13}{|c|}{ Absolute and relative frequencies } \\
\hline & & $\begin{array}{c}\text { THR } \\
(\mathrm{n}=10)\end{array}$ & $\begin{array}{c}\text { TYR } \\
(\mathrm{n}=8)\end{array}$ & $\begin{array}{l}\mathrm{COL} \\
(\mathrm{n}=6)\end{array}$ & $\begin{array}{l}\text { TRO } \\
(\mathrm{n}=6)\end{array}$ & $\begin{array}{l}\text { PAS } \\
(\mathrm{n}=5)\end{array}$ & $\begin{array}{l}\mathrm{DEN} \\
(\mathrm{n}=5)\end{array}$ & $\begin{array}{l}\text { TUR } \\
(\mathrm{n}=3)\end{array}$ & $\begin{array}{l}\text { FUR } \\
(\mathrm{n}=2)\end{array}$ & $\begin{array}{c}\text { PIC } \\
(n=1)\end{array}$ & $\begin{array}{l}\mathrm{CON} \\
(\mathrm{n}=1)\end{array}$ & $\begin{array}{c}\mathrm{ICT} \\
(\mathrm{n}=1)\end{array}$ & $\begin{array}{l}\text { THA } \\
(\mathrm{n}=1)\end{array}$ & $\begin{array}{c}\text { HIR } \\
(\mathrm{n}=1)\end{array}$ \\
\hline Pantoea agglomerans & $18(36.0 \%)$ & $2(20.0 \%)$ & $1(25.5 \%)$ & $2(33.3 \%)$ & $1(16.6 \%)$ & $3(60.0 \%)$ & $3(60.0 \%)$ & $1(33.3 \%)$ & $1(50.0 \%)$ & $1(100.0 \%)$ & $1(100.0 \%)$ & $1(100.0 \%)$ & $1(100.0 \%)$ & $0(0 \%)$ \\
\hline Escherichia coli & $13(26.0 \%)$ & $1(10.0 \%)$ & $1(25.5 \%)$ & $3(50.0 \%)$ & $0(0 \%)$ & $2(40.0 \%)$ & $3(60.0 \%)$ & $2(66.6 \%)$ & $1(50.0 \%)$ & $0(0 \%)$ & $0(0 \%)$ & $0(0 \%)$ & $0(0 \%)$ & $0(0 \%)$ \\
\hline Serratia rubidaea & $7(14.0 \%)$ & $0(0 \%)$ & $1(25.5 \%)$ & $2(33.3 \%)$ & $0(0 \%)$ & $1(20.0 \%)$ & $1(20.0 \%)$ & $1(33.3 \%)$ & $0(0 \%)$ & $1(100.0 \%)$ & $0(0 \%)$ & $0(0 \%)$ & $0(0 \%)$ & $0(0 \%)$ \\
\hline Hafnia alvei & $5(10.0 \%)$ & $1(10.0 \%)$ & $0(0 \%)$ & $0(0 \%)$ & $0(0 \%)$ & $1(20.0 \%)$ & $2(40.0 \%)$ & $1(33.3 \%)$ & $0(0 \%)$ & $0(0 \%)$ & $0(0 \%)$ & $0(0 \%)$ & $0(0 \%)$ & $0(0 \%)$ \\
\hline Enterobacter gergoviae & $2(4.0 \%)$ & $0(0 \%)$ & $0(0 \%)$ & $0(0 \%)$ & $0(0 \%)$ & $1(20.0 \%)$ & $0(0 \%)$ & $1(33.3 \%)$ & $0(0 \%)$ & $0(0 \%)$ & $0(0 \%)$ & $0(0 \%)$ & $0(0 \%)$ & $0(0 \%)$ \\
\hline Edwardsiella tarda & $2(4.0 \%)$ & $0(0 \%)$ & $0(0 \%)$ & $0(0 \%)$ & $0(0 \%)$ & $0(0 \%)$ & $1(20.0 \%)$ & $0(0 \%)$ & $0(0 \%)$ & $0(0 \%)$ & $0(0 \%)$ & $0(0 \%)$ & $1(100.0 \%)$ & $0(0 \%)$ \\
\hline Klebsiella pneumoniae & $1(2.0 \%)$ & $0(0 \%)$ & $0(0 \%)$ & $0(0 \%)$ & $0(0 \%)$ & $1(20.0 \%)$ & $0(0 \%)$ & $0(0 \%)$ & $0(0 \%)$ & $0(0 \%)$ & $0(0 \%)$ & $0(0 \%)$ & $0(0 \%)$ & $0(0 \%)$ \\
\hline Proteus vulgaris & $1(2.0 \%)$ & $0(0 \%)$ & $0(0 \%)$ & $0(0 \%)$ & $0(0 \%)$ & $0(0 \%)$ & $0(0 \%)$ & $1(33.3 \%)$ & $0(0 \%)$ & $0(0 \%)$ & $0(0 \%)$ & $0(0 \%)$ & $0(0 \%)$ & $0(0 \%)$ \\
\hline Proteus mirabilis & $1(2.0 \%)$ & $0(0 \%)$ & $0(0 \%)$ & $0(0 \%)$ & $0(0 \%)$ & $0(0 \%)$ & $0(0 \%)$ & $0(0 \%)$ & $0(0 \%)$ & $0(0 \%)$ & $1(100.0 \%)$ & $0(0 \%)$ & $0(0 \%)$ & $0(0 \%)$ \\
\hline Cronobacter sakazakii & $1(2.0 \%)$ & $0(0 \%)$ & $0(0 \%)$ & $1(16.6 \%)$ & $0(0 \%)$ & $0(0 \%)$ & $0(0 \%)$ & $0(0 \%)$ & $0(0 \%)$ & $0(0 \%)$ & $0(0 \%)$ & $0(0 \%)$ & $0(0 \%)$ & $0(0 \%)$ \\
\hline Enterobacter cloacae & $1(2.0 \%)$ & $0(0 \%)$ & $0(0 \%)$ & $0(0 \%)$ & $0(0 \%)$ & $0(0 \%)$ & $1(20.0 \%)$ & $0(0 \%)$ & $0(0 \%)$ & $0(0 \%)$ & $0(0 \%)$ & $0(0 \%)$ & $0(0 \%)$ & $0(0 \%)$ \\
\hline Arizona spp & $1(2.0 \%)$ & $0(0 \%)$ & $0(0 \%)$ & $0(0 \%)$ & $0(0 \%)$ & $0(0 \%)$ & $1(20.0 \%)$ & $0(0 \%)$ & $0(0 \%)$ & $0(0 \%)$ & $0(0 \%)$ & $0(0 \%)$ & $0(0 \%)$ & $0(0 \%)$ \\
\hline Yersinia enterocolitica & $1(2.0 \%)$ & $0(0 \%)$ & $0(0 \%)$ & $0(0 \%)$ & $0(0 \%)$ & $0(0 \%)$ & $1(20.0 \%)$ & $0(0 \%)$ & $0(0 \%)$ & $0(0 \%)$ & $0(0 \%)$ & $0(0 \%)$ & $0(0 \%)$ & $0(0 \%)$ \\
\hline Shigella spp & $1(2.0 \%)$ & $0(0 \%)$ & $0(0 \%)$ & $0(0 \%)$ & $0(0 \%)$ & $0(0 \%)$ & $0(0 \%)$ & $0(0 \%)$ & $1(50.0 \%)$ & $0(0 \%)$ & $0(0 \%)$ & $0(0 \%)$ & $0(0 \%)$ & $0(0 \%)$ \\
\hline
\end{tabular}

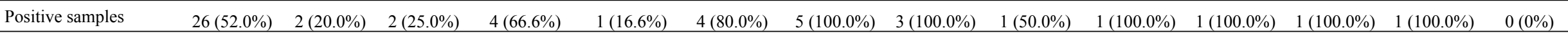
$\mathrm{THR}=$ Thraupidae, $\mathrm{TYR}=$ Tyrannidae, $\mathrm{COL}=$ Columbidae, $\mathrm{TRO}=$ Trochilidae, $\mathrm{PAS}=$ Passerellidae, DEN=Dendrocolaptidae, TUR=Turdidae, FUR $=$ Furnariidae $, \mathrm{PIC}=\mathrm{Picidae}, \mathrm{CON}=$ Conopophagidae, ICT= Icteridae, THA= Thamnophilidae, HIR= Hirundinidae 

other hand, all species of the Dendrocolaptidae, Turdidae, Picidae, Conopophagidae,

216 Icteridae and Thamnophilidae family had at least one bacterial isolate. In the

217 Trochilidae family, there was only one (1/6 species) bird that presented bacterial growth, which was a Rufous-breasted Hermit (Glaucis hirsutus) that was positive for Pantoea agglomerans. Another family with a low number of positive birds was Thraupidae that presented only two birds positive for enterobacteria ( $2 / 10$ species). An Orange-headed Tanager (Thlypopsis sordida) was positive for Hafnia alvei and Pantoea agglomerans, whereas a Bananaquit (Coereba flaveola) was positive for Pantoea agglomerans and Escherichia coli. The Tyrannidae family had the same number of positive birds (2/8 species), two individuals of Yellow-bellied Elaenia (Elaenia flavogaster) from which Pantoea agglomerans and Serratia rubidaea were isolated from one sample and Escherichia coli was isolated from the other. Lafresnaye's Woodcreeper (Xiphorhynchus guttatoides eytoni) was the species with the highest number of isolated enterobacteria (Enterobacter cloacae, Serratia rubidaea, Escherichia coli, Edwardsiella tarda, Hafnia alvei and Arizona spp). The Red-necked had no isolates, while the species Ceara Gnateater (Conopophaga cearae) classified as vulnerable (VU) was positive for Proteus mirabilis and Pantoea agglomerans (Table 3).

Table 3. Bacterial species isolated from free-living wild birds captured in the city of Mulungu, Ceará, Brazil

\begin{tabular}{lcc}
\hline Family & Common and scientific name & Isolated species of \\
\hline Thraupidae & Enterobacteriaceae \\
Red-necked Tanager (Tangara cyanocephala & - \\
Burnished-buff Tanager (Stilpnia cayana) & - \\
Bananaquit (Coereba flaveola) & - \\
Palm Tanager (Thraupis palmarum) & - \\
Red-necked Tanager (Tangara cyanocephala & - \\
cearensis) & - \\
Palm Tanager (Thraupis palmarum) & - \\
Palm Tanager (Thraupis palmarum) & - \\
Guira Tanager (Hemithraupis guira) & Hafnia alvei / Pantoea \\
Orange-headed Tanager (Thlypopsis sordida) & agglomerans \\
Bananaquit (Coereba flaveola) & Pantoea agglomerans / \\
Gscherichia coli
\end{tabular}


Columbidae

Passerellidae

Dendrocolaptidae

Turdidae

Furnariidae

Picidae

Conopophagidae
Short-crested Flycatcher (Myiarchus ferox)

Yellow-bellied Elaenia (Elaenia flavogaster)

Yellow-bellied Elaenia (Elaenia flavogaster)

Yellow-bellied Elaenia (Elaenia flavogaster)

Yellow-bellied Elaenia (Elaenia flavogaster)

Gray-fronted Dove (Leptotila rufaxilla) Pantoea agglomerans/Serratia

Gray-fronted Dove (Leptotila rufaxilla)

Ruddy Ground-Dove (Columbina talpacoti)

Ruddy Ground-Dove (Columbina talpacoti)

Ruddy Ground-Dove (Columbina talpacoti)

Ruddy Ground-Dove (Columbina talpacoti)

rubidaea

Escherichia coli

Pantoea agglomerans/

Escherichia coli

Escherichia coli/ Cronobacter sakazakii/Serratia rubidaea

\begin{tabular}{|c|c|}
\hline $\begin{array}{c}\text { Ruby-topaz Hummingbird (Chrysolampis } \\
\text { mosquitus) }\end{array}$ & - \\
\hline Woodnymph (Thalurania furcata) & - \\
\hline Rufous-breasted Hermit (Glaucis hirsutus) & - \\
\hline Rufous-breasted Hermit (Glaucis hirsutus) & - \\
\hline Rufous-breasted Hermit (Glaucis hirsutus) & Pantoea agglomerans \\
\hline Woodnymph (Thalurania furcata) & - \\
\hline Pectoral Sparrow (Arremon taciturnus) & $\begin{array}{c}\text { Escherichia coli/Pantoec } \\
\text { agglomerans }\end{array}$ \\
\hline Pectoral Sparrow (Arremon taciturnus) & Escherichia coli \\
\hline Pectoral Sparrow (Arremon taciturnus) & $\begin{array}{r}\text { Pantoea agglomerans/Haf } \\
\text { alvei/Serratia rubidaea/Kleb. }\end{array}$ \\
\hline Pectoral Sparrow (Arremon taciturnus) & $\begin{array}{c}\text { pneumoniae } \\
\text { Enterobacter gergoviae/Pan } \\
\text { agglomerans }\end{array}$ \\
\hline Pectoral Sparrow (Arremon taciturnus) & - \\
\hline $\begin{array}{l}\text { Straight-billed Woodcreeper (Dendroplex } \\
\text { picus) }\end{array}$ & Escherichia coli \\
\hline $\begin{array}{l}\text { Straight-billed Woodcreeper (Dendroplex } \\
\text { picus) }\end{array}$ & Pantoea agglomeral \\
\hline $\begin{array}{c}\text { Planalto Woodcreeper (Dendrocolaptes } \\
\text { platyrostris) }\end{array}$ & $\begin{array}{l}\text { Hafnia alvei/ Pantoea } \\
\text { agglomerans }\end{array}$ \\
\hline
\end{tabular}

Lafresnaye's Woodcreeper (Xiphorhynchus guttatoides eytoni)

Enterobacter cloacae/ Serratia rubidaea / Escherichia coli /

Edwardsiella tarda / Hafnia alvei / Arizona spp

Red-billed Scythebill (Campylorhamphus trochilirostris)

Pale-breasted Thrush (Turdus leucomelas)

Rufous-bellied Thrush (Turdus rufiventris)

Pantoea agglomerans / Yersinia enterocolitica / Escherichia coli

Proteus vulgaris

Pantoea agglomerans/Serratia rubidaea/Escherichia coli /

Enterobacter gergoviae

Rufous-bellied Thrush (Turdus rufiventris) Hafnia alvei / Escherichia coli

Pale-legged Hornero (Furnarius leucopus) Pantoea agglomerans/Shigella

Pale-legged Hornero (Furnarius leucopus)

\begin{tabular}{cc}
$\begin{array}{c}\text { Green-barred Woodpecker (Colaptes } \\
\text { melanochloros) }\end{array}$ & $\begin{array}{c}\text { Pantoea agglomerans / Serratia } \\
\text { rubidaea }\end{array}$ \\
\hline Ceara Gnateater (Conopophaga cearae) & Proteus mirabilis/Pantoea
\end{tabular}




\begin{tabular}{cc}
\hline & agglomerans \\
\hline Variable Oriole (Icterus pyrrhopterus) & Pantoea agglomerans \\
\hline Great Antshrike (Taraba major) & $\begin{array}{c}\text { Pantoea } \\
\text { agglomerans/Edwardsiella } \\
\text { tarda/Serratia rubidaea }\end{array}$ \\
\hline $\begin{array}{c}\text { Southern Rough-winged Swallow } \\
\text { (Stelgidopteryx ruficollis) }\end{array}$ & - \\
\hline
\end{tabular}

Considering the total of evaluated strains, the highest rate of antimicrobial resistance occurred to ampicillin 47.3\% (26/55). Even after the exclusion of intrinsic resistance (Klebsiella pneumonia and Hafnia alvei), the rate of $41.8 \%$ (23 strains) was still the highest result. After excluding cases of intrinsic resistance (Hafnia alvei), nalidixic acid with a rate of $36.3 \%(20 / 55)$ and amoxicillin associated with Clavulanic Acid with $32.7 \%(18 / 55)$, were the second and third antimicrobials with the highest resistance rates. Tobramycin, ciprofloxacin and tetracycline were the drugs that showed the best efficacy with rates of $96.4 \%, 92.6 \%$ and $90.9 \%$ respectively. Meropenem and Gentamicin also performed well (85.5\% and $81.8 \%$ efficacy, respectively). Considering E. coli, the highest resistance rate was also detected to ampicillin, 53.8\% (7/13). In contrast, all strains were sensitive to Ciprofloxacin. Regarding the Cronobacter sakazakii and Enterobacter cloacae strains, both showed resistance only to Nalidixic Acid (Table 4). 
Table 4. Absolute and relative frequencies of antimicrobial-resistant enterobacteria isolated from cloacal swab samples of wild birds captured from October to December 2019 in the city of Mulungu, Ceará, Brazil

\begin{tabular}{|c|c|c|c|c|c|c|c|c|c|c|c|}
\hline Enterobacteriaceae & GEN & AZI & TOB & AMP & CEF & $\mathrm{AMO}+\mathrm{AC} . \mathrm{CLA}$ & CIP & TET & SUL & AC. NAL & MER \\
\hline & $\mathrm{n}(\%)$ & $\mathrm{n}(\%)$ & $\mathrm{n}(\%)$ & $\mathrm{n}(\%)$ & $\mathrm{n}(\%)$ & $\mathrm{n}(\%)$ & $\mathrm{n}(\%)$ & $\mathrm{n}(\%)$ & $\mathrm{n}(\%)$ & $\mathrm{n}(\%)$ & $\mathrm{n}(\%)$ \\
\hline Pantoea agglomerans, $\mathrm{n}=18$ & $4(22.2 \%)$ & $5(27.7 \%)^{*}$ & - & $7(38.9 \%)$ & $3(16.6 \%)$ & $9(50 \%)$ & $1(5.5 \%)$ & - & - & $7(38.9 \%)$ & $2(11.1 \%)$ \\
\hline Escherichia coli, $\mathrm{n}=13$ & $1(7.7 \%)$ & $2(15.4 \%)^{*}$ & $1(7.7 \%)$ & $7(53.8 \%)$ & $2(15.4 \%)$ & $2(15.4 \%)$ & - & $1(7.7 \%)$ & $2(15.4 \%)$ & $2(15.4 \%)$ & $1(7.7 \%)$ \\
\hline Serratia rubidae, $\mathrm{n}=7$ & $2(28.6 \%)$ & $2(28.6 \%)^{*}$ & - & $4(57.1 \%)$ & $2(28.6 \%)$ & $1(14.3 \%)$ & $1(14.3 \%)$ & $1(14.3 \%)$ & - & $3(42.8 \%)$ & $2(28.6 \%)$ \\
\hline Hafnia alvei, $\mathrm{n}=5$ & - & $2(40.0 \%)^{*}$ & - & $2(40 \%)^{*}$ & $1(20 \%)$ & $2(40 \%)^{*}$ & - & $1(20 \%)$ & $2(40 \%)$ & $2(40 \%)$ & - \\
\hline Enterobacter gergoviae, $\mathrm{n}=2$ & $1(50 \%)$ & - & - & $1(50 \%)$ & - & $1(50 \%)$ & - & - & - & - & - \\
\hline Edwardsiella tarda, $\mathrm{n}=2$ & - & $2(100 \%)^{*}$ & - & $1(50 \%)$ & - & $2(100 \%)$ & $1(50 \%)$ & - & - & - & - \\
\hline Klebsiella pneumonia, $\mathrm{n}=1$ & $1(100 \%)$ & - & - & $1(100 \%)^{*}$ & $1(100 \%)$ & $1(100 \%)$ & $1(100 \%)$ & - & - & $1(100 \%)$ & $1(100 \%)$ \\
\hline Proteus vulgaris, $\mathrm{n}=1$ & - & $1(100 \%)^{*}$ & - & - & $1(100 \%)$ & $1(100 \%)$ & - & $1(100 \%)^{*}$ & - & $1(100 \%)$ & $1(100 \%)$ \\
\hline Proteus mirabilis, $\mathrm{n}=1$ & - & $1(100 \%)^{*}$ & - & - & $1(100 \%)$ & - & - & - & - & $1(100 \%)$ & - \\
\hline Cronobacter sakazakii, $\mathrm{n}=1$ & - & - & - & - & - & - & - & - & - & $1(100 \%)$ & - \\
\hline Enterobacter cloacae, $\mathrm{n}=1$ & - & - & - & - & - & - & - & - & - & $1(100 \%)$ & - \\
\hline Arizona $\mathrm{spp}, \mathrm{n}=1$ & - & - & - & $1(100 \%)$ & - & $1(100 \%)$ & - & - & - & - & - \\
\hline Yersinia enterocolitica, $\mathrm{n}=1$ & - & $1(100 \%)^{*}$ & - & $1(100 \%)$ & - & - & - & - & - & - & - \\
\hline Shigella $\mathrm{spp}, \mathrm{n}=1$ & $1(100 \%)$ & $1(100 \%)$ & $1(100 \%)$ & $1(100 \%)$ & - & - & $1(100 \%)$ & $1(100 \%)$ & $1(100 \%)$ & $1(100 \%)$ & $1(100 \%)$ \\
\hline Acquired resistance & $10(18.2 \%)$ & $1(1.8)$ & $2(3.6 \%)$ & $23(41.8 \%)$ & $11(20 \%)$ & $18(32.7 \%)$ & $5(9.1 \%)$ & $4(7.8)$ & $5(9.1 \%)$ & $20(36.3 \%)$ & $8(14.5)$ \\
\hline Total resistance (acquired + intrinsic) & $10(18.2 \%)$ & $17(30.9)^{*}$ & $2(3.6 \%)$ & $26(47.3 \%)^{*}$ & $11(20 \%)$ & $20(36.3 \%)$ & $5(9.1 \%)$ & $5(9.1 \%)^{*}$ & $5(9.1 \%)$ & $20(36.3 \%)$ & $8(14.5)$ \\
\hline
\end{tabular}



resistance in samples collected from the Red-necked Tanager (Tangara cyanocephala cearensis), since there was no isolation of any bacteria. However, the Proteus mirabilis strain that was isolated from a Ceara Gnateater (Conopophaga cearae) was resistant to azithromycin, ceftriaxone and nalidixic acid. In addition, the Pantoea agglomerans strain that was isolated from the same individual was resistant to eight out of twelve tested antibiotics (gentamicin, nalidixic acid, ceftriaxone, amoxicillin + clavulanic acid, ciprofloxacin, ampicillin, ciprofloxacin and meropenem), which correspond to five of the seven antimicrobial classes.

As expected, when considering the bacterial species that have intrinsic resistance mechanisms, resistance to at least one of the tested antimicrobials was observed in all of the strains. However, when considering only acquired resistance, 10 isolates $(18.2 \%)$ were sensitive to all of the investigated drugs. Multidrug resistance (acquired cases) was observed in 13 isolates (23.5\%), and three strains were resistant to seven antibiotics. From the total of 13 Escherichia coli strains, 2/13 (7.7\%) presented multidrug resistance and $4 / 13(30.8 \%)$ of the strains were sensitive to all of the studied antimicrobials (Table $5)$.

Table 5. Absolute and relative frequencies of resistance to multiple drugs of Enterobacteriaceae strains isolated from cloacal swabs from free-living birds captured in the city of Mulungu, Ceará, Brazil

\begin{tabular}{cccc}
\hline \multirow{2}{*}{$\begin{array}{c}\text { Number of } \\
\text { antibiotic } \\
\text { classes }\end{array}$} & $\begin{array}{c}\text { Frequency of } \\
\text { resistant Escherichia } \\
\text { coli }(\%)\end{array}$ & $\begin{array}{c}\text { Only acquired } \\
\text { resistance }(\%)\end{array}$ & $\begin{array}{c}\text { Total resistance } \\
\text { intrinsic + acquired) } \\
(\%)\end{array}$ \\
\hline 0 & $4(30.8 \%)$ & $10(18.2 \%)$ & - \\
1 & $5(38.4 \%)$ & $20(36.4 \%)$ & $10(18.2 \%)$ \\
2 & $2(15.4 \%)$ & $12(21.9 \%)$ & $22(40 \%)$ \\
3 & $1(7.7 \%)$ & $5(9.1 \%)$ & $13(23.7 \%)$ \\
4 & - & $2(3.6 \%)$ & $3(5.4 \%)$ \\
5 & $1(7.7 \%)$ & $3(5.4 \%)$ & $3(5.4 \%)$ \\
6 & - & - & $1(1.9 \%)$ \\
7 & - & $3(5.4 \%)$ & $3(5.4 \%)$ \\
\hline
\end{tabular}




\section{Discussion}

In this study, more than half of the samples were positive to some of the investigated enterobacteria. Despite the isolation of fourteen different species of bacteria, birds were not necessarily suffering from any pathological condition. In addition to the low frequency of isolation, some of these microorganisms may occur naturally in these birds, considering that these strains have been isolated previously from healthy birds either in the wild or in cages [40, 41, 42, 43, 44, 45, 30]. Species of the Enterobacteriaceae family, Escherichia coli in particular, do not belong to the intestinal microbiota of granivorous pet birds, because feed composed exclusively of seeds has been shown to provoke an inhibitory effect of this bacterial species [46]. In this sense, the detection of Enterobacteriaceae in cloacal samples of granivorous birds should be observed with caution, as it suggests favorable conditions for the development of potential pathologies [47]. However, it is important to highlight that the bird species that were captured in this study have an omnivorous diet. This may explain the natural presence of enterobacteria, since the occurrence of these microorganisms in the digestive tract is influenced by the composition of their nutrition [46]. Other factors may also have influenced the isolation of these bacteria, such as direct or indirect contact with domestic animals, as well as environmental contamination by human action. In the natural environment in which they live, several species of enterobacteria also occur, as they are ubiquitous, in soil or water. Thus, Enterobacteriaceae have been isolated mainly from omnivorous, piscivorous and healthy carnivore birds [46, 48, 49, $50,51]$.

The most prevalent bacterial species isolated from birds in this study was Pantoea agglomerans. This microorganism can rarely cause infections, while it normally acts as a commensal species that colonizes the normal intestinal microbiota.

314 Biodiversity studies report the isolation of Pantoea agglomerans in the microbiota of several plants and insects $[52,53]$, which serve as a food source for several of the bird species that were captured. Escherichia coli was also among the most isolated microorganisms $(23.2 \%)$ and is likewise an ubiquitous organism, which can be found in soil, water and vegetation $[54,55]$. Although its presence does not necessarily mean a sign of illness, on some occasions, such as when they acquire virulence genes, this 
321 The prevalence of E. coli in studies involving free-ranging birds is quite varied. Saviolli

322 [56] describes the presence of the microorganism in $60.0 \%$ of samples from

323 Magnificent Frigatebird (Fregata magnificens) from the coast of the State of São Paulo.

324 Vilela et al. [57] investigated this microorganism in fecal samples of House Sparrows

325 (Passer domesticus) that lived around farms in the State of Pernambuco and found

326 lower percentages (13.2\%). Callaway et al. [58] analyzed cloacal swab samples from

327376 migratory birds, which included Brown-Headed Cowbird (Molothrus ater),

328 Common Grackle (Quiscalus quiscula) and Cattle Egret (Bubulcus ibis), and found even lower rates, $3.7 \%(14 / 376)$.

330 Serratia rubidea was the third most isolated species of bacteria. It is considered an important human pathogen as a common agent of nosocomial infections mainly of the urinary tract [59]. Diseases caused by Serratia in birds are uncommon but can occur mostly in an opportunistic manner in immunocompromised birds due to stress in captivity, inappropriate weather conditions, parasitic diseases, among other causes [60, 61]. Free-living birds can either acquire this microorganism from the contaminated environment in which they live and may act as disseminators. Spena et al. [62] isolated Serratia rubidea from oral swab samples of Eurasian Thick-knee (Burhinus oedicnemus) and associated this finding with a diet composed of invertebrates found in the feces of ruminants. This bacterial species has also been reported to be isolated from lake waters in Poland, which was occupied by Great Cormorant (Phalacrocorax carbo). Researchers have associated this finding with the leaching of feces and excreta during rains leading this and other species of enterobacteria into the lake [63].

The other enterobacteria that occurred less frequently in the analyzed samples can also occasionally cause damage to health and reports have already been described in the scientific literature involving free-range or domestic birds. In addition to sharing virulence factors with other enteropathogens, such as Escherichia coli, Hafnia alvei has been reported to cause serious infections in laying hens [64, 65]. Miniero Davies et al. [66] described an outbreak of mortality associated with E. tarda affecting fish, domestic ducks and a wild heron that shared a lake located on a farm in the state of São Paulo, Brazil. Davies et al. [67] described Klebsiella pneumoniae expressing virulence and antibiotic resistance genes in psittacine and passerine birds from illegal trade. Cronobacter sakazakii has been reported in broilers with clinical signs causing high mortality and decreased egg production [68]. Proteus sp. are also potentially pathogenic for birds as the cause of foot injuries and involvement of the respiratory system causing 
air sacculitis and caseous pneumonia in cases of immunosuppression [69]. Bacteria from the Arizona group have often been isolated from feces of adult chickens and turkeys but have also been reported to occur in wild birds, such as the Canadian crane $[70,71]$. However, more serious occurrences have been reported in industrial birds, such as mortality in turkeys, as well as clinical signs of Salmonellosis and omphalitis in broiler chickens $[72,1]$.

It is always more expected to detect cases of antimicrobial resistance in birds raised in captivity than those that live in the wild. In addition to the possibility of inappropriate use of antibiotics, this may occur when birds have greater contact with other animals that possess and disseminate resistant strains [73, 74]. However, our research showed cases of free-living bird strains with relevant antimicrobial resistance rates, mainly involving ampicillin, nalidixic acid and amoxicillin associated with clavulanic acid. Some studies involving free-living birds has also reported resistance to these three antibiotics in isolates of enterobacteria with varying rates. Carreira [75] researched samples of cloacal swabs from free-living birds captured in the Metropolitan region of Fortaleza, Brazil and observed that the acquired resistance rates of amoxicillin associated with clavulanic acid, as well as nalidixic acid, were lower than the results found in this study. Tsubokura et al. [76] analyzed Escherichia coli isolates from the feces of several migratory bird species collected in the coastal region of Japan found that less than $10 \%$ of the samples were resistant to ampicillin. These same researchers used the feces of 54-day-old Hyline chicks and found the resistance to ampicillin to be approximately $39.0 \%$. These variations can often be attributed to the conditions found in different habitats [77], as demonstrated by several studies that measure resistance levels in isolates from birds under different conditions or captured in different environments [78, 24, 79, 80, 81].

The rate of resistance to meropenem detected in free-living birds in this research should also be highlighted (14.5\%). Several studies involving wild birds, free-living or not, as well as domestic birds, present lower rates of resistance to this drug or none at all $[82,83,30,84,85]$. However, a more relevant point is the fact that this drug is a high cost carbapenemic with restricted use to hospitals in Brazil. In addition, it is a last resort for the treatment of infections and is widely prescribed to human patients with septic conditions in intensive care of severe infections by Gram-negative hospital pathogens, including Enterobacteriaceae [86, 87, 88]. Although the recommendations for the use of this drug are restricted, the reservoirs of these organisms are increasing, not only in 
hospitals, but also in the community and the environment. An important new source of resistance development of such organisms is observed in livestock, companion animals and wildlife [89].

Concerning the total number of isolated enterobacterial strains $(23.6 \%)$ and specifically Escherichia coli $(15.4 \%)$, worrisome rates of multidrug resistance were observed, considering that these are Gram-negative bacteria from free-living animals. Other studies have also demonstrated the occurrence of multidrug resistance of bacteria isolated from cloacal swabs in free-living birds $[90,85]$. However, it is not so simple to obtain a proper comparison of data from other studies, since there are few published articles specifically involving free-living birds and isolates of enterobacteria in general from cloacal swabs. One of these studies involves Gray-breasted Parakeets (Pyrrhura griseipectus), whose total bacterial isolates presented a lower multidrug resistance rate (11.1\%) [30]. Concerning Escherichia coli, it is possible to observe that the results in relation to multidrug resistance are the most varied. However, it is possible to find similar rates [15], percentages lower than $5.4 \%$ or higher than $23.1 \%[26,84]$.

Densely populated urban areas are historically seen as hotspots for antibiotic resistant bacteria $[91,92]$ but microorganisms with these characteristics associated with humans have been described in non-clinical environments, such as in remote areas of the planet, far from direct anthropogenic pressure, apparently free from exposure to antibiotics, as in regions of the Amazon, Bolivia and Antarctica. It is suspected that this resistance may have been caused by the existence in these regions of military bases, domestic animals, water, fishing boats, scientific expeditions and/or on-board tourism $[93,94,95,96,97]$. Although it is important to emphasize that the cause of antibiotic resistance may not always be related to environmental pressures caused by man, as is the case of those that are naturally induced by microorganisms that produce natural antibiotics [98].

The considerable resistance rates detected in isolates from birds captured in Mulungu, more particularly those tested with ampicillin, amoxicilin+clavulunate, meropenem and nalidixic acid, may indicate that some contact with anthropogenic residues has occurred. Thus, we can consider that wild birds included in our study may be working as indicators of environmental contamination. In this context, we found that free-living birds can be considered victims of the environment in which they live, acquiring multidrug resistant bacteria. At some point, this condition can harm the conservation of species, or they may act as reservoirs of resistant bacteria $[97,99,100$, 
423 101]. Thus, the emergence and evolution of antibiotic resistance among pathogenic

424 bacteria represent a serious public health issue on a global scale $[102,103]$.

425

\section{Conclusion}

This study revealed that the investigated wild free-living birds harbor a diverse 428 cloacal microbiota concerning the Enterobaceriaceae family. The phenotypic analysis of 429 the isolates revealed the occurrence of bacterial resistance to several of the antimicrobials tested. Among these, the resistance rates to ampicillin and nalidixic acid can be considered high, since these isolates originated from free-living animals, which naturally suffer a lower selective pressure by antibiotics than domestic ones. The percentage of resistance found to meropenem (14.5\%) was also higher than normally expected, since it is a drug with restricted use in hospitals. A relevant multidrug resistance rate was also detected in this study (23.5\%), and this shows that birds associated with local extinction risk, such as Ceara Gnateater (Conopophaga cearae), are also being affected.

Although this research did not investigate the direct or indirect relationship of wild birds in the Region of Mulungu-CE with sources of contamination, such as sewage water, dumps, crops, soil and domestic or wild animals, it is possible to assume that they could have some contact with contaminating agents, which explains the multidrug resistance rates detected in the cloacal microbiota isolates. Furthermore, birds that have been infected by these microorganisms may also be carrying resistant bacteria to other wild birds or to domestic animals.

\section{Author Contributions}

447 Conceptualization: Antonio Jackson Forte Beleza, Régis Siqueira de Castro Teixeira

448 Data curation: Antonio Jackson Forte Beleza

449 Formal analysis: William Cardoso Maciel, Arianne Silva Carreira

450 Funding acquisition: Antonio Jackson Forte Beleza, Adson Ribeiro Marques, Carlos

451 Henrique Guedes Nogueira

452 Investigation: Régis Siqueira de Castro Teixeira, Antonio Jackson Forte Beleza, Adson

453 Ribeiro Marques, Leandro Rodrigues Ribeiro, Neilton Monteiro Pascoal Filho 
454 Methodology: Régis Siqueira de Castro Teixeira, Antonio Jackson Forte Beleza, Bruno

455 Pessoa Lima

456 Project administration: Antonio Jackson Forte Beleza

457 Resources: Antonio Jackson Forte Beleza

458 Supervision: William Cardoso Maciel

459 Validation: William Cardoso Maciel, Isaac Neto Goes da Silva

460 Writing \pm review \& editing: Ruben Horn Vasconcelos, Régis Siqueira de Castro

461 Teixeira, Antonio Jackson Forte Beleza.

462

463

464

465

466

467

468

469

470

471

472

473

474

475

476

477

478

479

480

481

482

483

484

485

486

487

488

489

\section{Acknowledgments}

The authors would like to thank the Coordination for the Improvement of Higher Education Personnel (CAPES) for the financial support. We are also grateful for the fundamental logistical support given by Mr. Saulo Rocha from Fazenda Haras Claro, who provided accommodation for the entire team of researchers responsible for field activities.

\section{References}

1. Pacheco, GO.Isolation of Arizona hinshawii from broilers, breeding animals, incubation waste and components of poultry rations in Mexico. In: Proceedings of 29th Western Poultry Disease Conference, Acapulco, Mexico, 22-25 April 1980. Cooperative Extension, University., 1980. p. 215-218.

2. Ab’Sáber, Aziz Nacib. "Nordeste sertanejo: a região semi-árida mais povoada do mundo." Estudos avançados 13. 1999: 60-68. doi: https://doi.org/10.4000/nrt.1879

3. Farias JA. História do Ceará. 6 ${ }^{\mathrm{a}}$ ed. Fortaleza: Armazém da Cultura. 2012.

4. Studart GC. Geografia do Ceará. Fortaleza: Expressão Gráfica. 2010.

5. IBGE - INSTITUTO BRASILEIRO DE GEOGRAFIA E ESTATÍSTICA. 2014. Estados. Ceará. Disponível em http://www.ibge.gov.br/estadosat/per fil.php?lang=\&sigla=ce. Acesso em março de 2014.

6. Quinet Y, Hites N, de Biseau D'Hauteville JC, Oliveira T S, \& Araujo FS. Formigas (Hymenoptera Formicidae) da serra de Baturité, Ceará. in: T. S. Oliveira e F. S. Araújo (eds.). Biodiversidade e conservação da biota na serra de Baturité, Ceará. Fortaleza: Edições UFC, Coelce. 2007. PP. p.251-271. 
bioRxiv preprint doi: https://doi org/10.1101/2021.11.04.467336; this version posted November 4,2021 . The copyright holder for this preprint (which was not certified by peer review) is the author/funder, who has granted bioRxiv a license to display the preprint in perpetuity. It is made available under aCC-BY 4.0 International license.

7. Cavalcante AMB. A Serra de Baturité. Fortaleza: Edições Livro técnico, 2005. p.84.

8. Instituto Chico Mendes de Conservação da Biodiversidade (2018) Livro Vermelho da Fauna Brasileira Ameaçada de Extinção: Volume I/1. ed. Brasília: ICMBio, 492 p. (impresso). Acompanha Pen Card contendo: v.2. Mamíferos - v.3. Aves - v.4. Répteis - v.5. Anfíbios - v.6. Peixes - v.7 Invertebrados.

9. Nunes FP, Lopes I T. Aves da Serra de Baturité: Guia Fotográfico. Ceará; Aquasis. p.180. 2015.

10. Biondo D, Pletsch JÁ, Guzzo GB. Impactos da ação antrópica em indivíduos da fauna silvestre de Caxias do Sul e região: uma abordagem ex situ. Revista Brasileira de Biociências. 2019; v. 17, n. 1. Disponível em http://www.ufrgs.br/seerbio/ojs/index.php/rbb/article/view/4183

11. Silva MA, Marvulo MF, Mota RA, Silva JC. A importância da ordem Ciconiiformes na cadeia epidemiológica de Salmonella spp. para a saúde pública e a conservação da diversidade biológica. Pesquisa Veterinária Brasileira, v. 30, p. 573-580, 2010. https://doi.org/10.1590/S0100-736X2010000700011

12. De Morais ABC, Ribeiro MG, Listoni FP. Enteropatógenos de potencial zoonótico identificados em aves silvestres. Veterinária e Zootecnia. 2019. v. 26, p. 1-16. https://doi.org/10.35172/rvz.2019.v26.404

13. Waldenström J, Broman T, Carlsson I, Hasselquist D, Achterberg RP, Wagenaar JA, Olsen B. Prevalence of Campylobacter jejuni, Campylobacter lari, and Campylobacter coli in different ecological guilds and taxa of migrating birds. Applied and Environmental Microbiology. 2002. v. 68, n. 12, p. 5911-5917. https://doi.org/10.1128/AEM.68.12.5911-5917.2002

14. Maul JD, Gandhi JP, Farris JL. Community-level physiological profiles of cloacal microbes in songbirds (Order: Passeriformes): variation due to host species, host diet, and habitat. Microbial ecology. 2005. v. 50, n. 1, p. 19-28. https://doi.org/10.1007/s00248-004-0076-9

15. Machado DN, Lopes ES, Albuquerque AH, Horn RV, Bezerra WGA, Siqueira RAS, Cardoso WM. Isolation and Antimicrobial Resistance Profiles of Enterobacteria from Nestling Grey-Breasted Parakeets (Pyrrhura Griseipectus). Brazilian Journal of Poultry Science. 2018. v.20, p. 103-110. https://doi.org/10.1590/1806-9061-2017$\underline{0551}$

16. Palmgren H, Sellin M, Bergström S, Olsen B. Enteropathogenic bacteria in migrating birds arriving in Sweden. Scandinavian Journal of Infectious Diseases. 1997. v. 29, n. 6, p. 565-568. https://doi.org/10.3109/00365549709035895

17. Gabriel I, Mallet S, Sibille P. La microflore digestive des volailles: facteurs de variation et conséquences pour l'animal. PRODUCTIONS ANIMALES-PARIS- 
bioRxiv preprint doi: https://doi org/10.1101/2021.11.04.467336; this version posted November 4,2021 . The copyright holder for this preprint (which was not certified by peer review) is the author/funder, who has granted bioRxiv a license to display the preprint in perpetuity. It is made available under aCC-BY 4.0 International license.

INSTITUT NATIONAL DE LA RECHERCHE AGRONOMIQUE-. 2005. v. 18, n. 5, p. 309. https://doi.org/10.20870/productions-animales.2005.18.5.3535

18. Saullu J. (2009). Saúde intestinal das aves e suas interações. 2007.

19. Santos, T., Silva, N., Igrejas, G., Rodrigues, P., Micael, J., Rodrigues, T., ... \& Poeta, P. Dissemination of antibiotic resistant Enterococcus spp. and Escherichia coli from wild birds of Azores Archipelago. Anaerobe. 2013. v. 24, p. 25-31. https://doi.org/10.1016/j.anaerobe.2013.09.004

20. Smith S, Wang J, Fanning S, McMahon BJ. Antimicrobial resistant bacteria in wild mammals and birds: a coincidence or cause for concern?. Irish Veterinary Journal. 2014. v.67, n.8, p. 1-3. https://doi.org/10.1186/2046-0481-67-8

21. Stedt, J., Bonnedahl, J., Hernandez, J., McMahon, B. J., Hasan, B., Olsen, B., ... \& Waldenström, J. Antibiotic resistance patterns in Escherichia coli from gulls in nine European countries. Infection Ecology and Epidemiology. 2014. v. 4, n. 215, p.1-10. https://doi.org/10.3402/iee.v4.21565

22. WHO. 2014. Antimicrobial Resistance: Global Report on Surveillance. Geneva: World Health Organization 2014.

23. Wellington EM, Boxall A B, Cross P, Feil EJ, Gaze WH, Hawkey PM, JohnsonRollings AS, Jones DL, Lee NM, Otten W, Thomas CM, Williams AP. The role of the natural environment in the emergence of antibiotic resistance in gram-negative bacteria. Lancet Infectious Diseases. 2013. 13(2), 155-165. https://doi.org/10.1016/S1473-3099(12)70317-1

24. Atterby C, Ramey AM, Hall GG, Järhult J, Börjesson S, Bonnedahl J. Increased prevalence of antibiotic-resistant E. coli in gulls sampled in Southcentral Alaska is associated with urban environments. Infection ecology \& epidemiology. 2016. v. 6, n. 1, p. 32334. https://doi.org/10.3402/iee.v6.32334

25. Arnold KE, Williams NJ, Bennett M.'Disperse abroad in the land': the role of wildlife in the dissemination of antimicrobial resistance. Biology Letters. 2016. v. 12, n. 8, p. 20160137. https://doi.org/10.1098/rsbl.2016.0137

26. Carroll D, Wang J, Fanning S, McMahon BJ. Antimicrobial resistance in wildlife: implications for public health. Zoonoses and public health. 2015. v. 62, n. 7, p. 534542. https://doi.org/10.1111/zph.12182

27. Huijbers PM, Blaak H, De Jong MC, Graat EA, Vandenbroucke-Grauls CM, De Roda Husman AM. Role of the environment in the transmission of antimicrobial resistance to humans: a review. Environmental science \& technology. 2015. v. 49, n. 20, p. 11993-12004. https://doi.org/10.1021/acs.est.5b02566

28. Tavares SS. Aspectos biológicos, fisiológicos e patológicos de carcarás (Caracara plancus, miller, j. f., 1777) capturados na área do aeroporto internacional pinto martins, Fortaleza-CE. Dissertação (Mestrado em Ciências Veterinárias) 
Universidade Estadual do Ceará, 2014. Disponivel em: http://www.uece.br/ppgcvwp/wpcontent/uploads/sites/6/2019/08/SamuelSalgado_Disserta\%C3\%A7\%C3\%A3o.pdf

29. Mendonça SV. Caracterização hematológica, bioquímica, morfométrica e microbiológica de falcões peregrinos (Falco peregrinus)de vida livre. Dissertação (Mestrado em Ciências Veterinárias) Universidade Estadual do Ceará, 2015. Disponivel em: https://sucupira.capes.gov.br/sucupira/public/consultas/coleta/trabalhoConclusao/vie wTrabalhoConclusao.jsf?popup $=$ true \&id trabalho $=2407537$

30. Beleza AJF, Maciel WC, Carreira AS, Marques AR, Nunes FP, Raso TF, Teixeira RS. Antimicrobial susceptibility profile of enterobacteria isolated from wild greybreasted parakeets (Pyrrhura griseipectus). Pesquisa Veterinária Brasileira. 2021. v. 41. https://doi.org/10.1590/1678-5150-PVB-6696

31. Oliveira TS et al. Histórico dos impactos antrópicos e aspectos geoambientais da serra de Barturité, Ceará. In: OLIVEIRA, T. S.; ARAÚJO, F. S. (Eds.) Eds.). Diversidade e conservação da biota da serra de Baturité, Ceará. Fortaleza: Edições UFC; COELCE, 2007. p. 1770.

32. IPECE. Perfil básico municipal. Fortaleza, 2012. Disponível em: $<$ http://www.ipece.ce.gov.br/publicacoes/perfil_basico/pbm2012/Guaramiranga .pdf $>$. Acesso em: 27 set. 2021.

\section{FUNDAÇÃO CEARENSE DE METEOROLOGIA E RECURSOS HÍDRICOS -} FUNCEME: "Dados pluviométricos do Ceará". Disponível em $<$ http://www.funceme.br/index.php/areas/23onitoramento/meteorolC3\%B3gico/633 -calend $\%$ C3\%A1rio-das-chuvas $>$ Acessado em outubro de 2015.

34. Sigrist T. Guia de Campo Avis Brasilis - Avifauna Brasileira. Avis Brasilis, São Paulo, 2014.

35. Pacheco JF, Silveira LF, Aleixo A, Agne CE, Bencke GA, Bravo GA, Brito, GRR, Cohn-Haft M, Maurício GN, Naka LN, Olmos F, Posso S, Lees AC, Figueiredo LFA, Carrano E, Guedes RC, Cesari E, Franz I,Schunck F, Piacentini VQ. Annotated checklist of the birds of Brazil by the Brazilian Ornithological Records Committeesecond edition. Ornithology Research. 2021 v. 29, n. 2, p. 94-105. https://doi.org/10.1007/s43388-021-00058-x.

36. Koneman EW, Procop GW, Church DL, Hall GS, Janda WM, Schreckenb P. Enterobacteriaceae. Diagnóstico Microbiológico: Texto e Atlas Colorido. 7. Ed. (pag. 230-290) Rio de Janeiro: Guanabara Koogan. 2018.

37. Bayer AW, Kirby WMM, Sherris JC, Turck M. Antibiotic susceptibility testing by a standardized single disc method. Am J clin pathol. 1966 v. 45, n. 4, p. 493-496.

38. Clinical and Laboratory Standards Institute (CLSI), 2019. Performance Standards for Antimicrobial Susceptibility Testing. 29th ed. Document M100-S29. 
39. Magiorakos AP, Srinivasan A, Carey RB, Carmeli Y, Falagas ME, Giske CG, Harbarth S, Hindler JF, Kahlmeter G, Olsson-Liljequist B, Paterson DL, Rice LB, Stelling J, Struelens MJ, Vatopoulos A, Weber JT, Monnet DL. Multidrug-resistant, extensively drug-resistant and pandrug-resistant bacteria: an international expert proposal for interim standard definitions for acquired resistance. Clinical microbiology and infection. 2012. v. 18, n. 3, p. 268-281. https://doi.org/10.1111/j.1469-0691.2011.03570.x

40. Santos HF, Flôres ML, Lara VM, Silva MS, Battisti L, Lovato LT. Cloacal microbiota identification and evaluation of the antimicrobial resistance in captive cracids from Rio Grande do Sul, Brazil. Pesquisa Veterinária Brasileira. 2010. v. 30, n. 12, p. 1077-1082, 2010. https://doi.org/10.1590/S0100-736X2010001200013

41. Lopes EDS, Maciel WC, De Albuquerque ÁH, Machado DN, Bezerra WDA, Vasconcelos RH, Teixeira RDC. Prevalence and antimicrobial resistance profile of enterobacteria isolated from psittaciformes of illegal wildlife trade. Acta Scientiae Veterinariae. 2015. v. 43.

42. Murugaiyan J, Krueger K, Roesler U, Weinreich J, Schierack P. Assessment of species and antimicrobial resistance among Enterobacteriaceae isolated from mallard duck faeces. Environmental monitoring and assessment. 2015. v. 187, n. 3, p. 1-11. https://doi.org/10.1007/s10661-015-4346-4

43. Horn RV, Cardoso WM, Lopes ES, Teixeira RS, Albuquerque ÁH, Rocha-e-Silva RC, Bezerra WG. Identification and antimicrobial resistance of members from the Enterobacteriaceae family isolated from canaries (Serinus canaria). Pesquisa Veterinária Brasileira. 2015. v. 35, p. 552-556. https://doi.org/10.1590/S0100736X2015000600011

44. Vaz FF, Serafini PP, Locatelli-Dittrich R, Meurer R, Durigon EL, Araújo JD, Raso TF. Survey of pathogens in threatened wild red-tailed Amazon parrot (Amazona brasiliensis) nestlings in Rasa Island, Brazil. brazilian journal of microbiology. 2017. v. 48, p. 747-753. https://doi.org/10.1016/j.bjm.2017.03.004

45. Beleza AJF, Maciel WC, Carreira AS, Bezerra WG, Carmo CC, Havt A, Teixeira RS. Detection of Enterobacteriaceae, antimicrobial susceptibility, and virulence genes of Escherichia coli in canaries (Serinus canaria) in northeastern Brazil. Pesquisa Veterinária Brasileira. 2019. v. 39, p. 201-208. https://doi.org/10.1590/1678-5150-PVB-5829

46. Glünder G. Influence of diet on the occurrence of some bacteria in the intestinal flora of wild and pet birds. DTW. Deutsche Tierarztliche Wochenschrift. 2002. v. 109, n. 6, p. 266-270. PMID: 12125172.

47. Di Francesco CE, Todisco G, Montani A, Profeta F, Di Provvido A, Foschi G, Marsilio F. Reproductive disorders in domestic canaries (Serinus canarius domesticus): A retrospective study on bacterial isolates and their antimicrobial 
resistance in Italy from 2009 to 2012. Vet. Ital. 2018. v. 54, p. 169-174. doi: 10.12834/VetIt.955.4952.2

48. Bangert RL, Ward ACS, Stauber EH, Cho BR, Widders PR. A survey of the aerobic bacteria in the feces of captive raptors. Avian Diseases. 1988. p. 53-62. https://doi.org/10.2307/1590948

49. Aruji Y, Tamura K, Sugita S, Adachi Y. Intestinal microflora in 45 crows in Ueno Zoo and the in vitro susceptibilities of 29 Escherichia coli isolates to 14 antimicrobial agents. Journal of veterinary medical science. 2004. v. 66, n. 10, p. 1283-1286. https://doi.org/10.1292/jvms.66.1283

50. Dobbin G, Hariharan H, Daoust PY, Hariharan S, Heaney S, Coles M, Muckle CA. Bacterial flora of free-living double-crested cormorant (Phalacrocorax auritus) chicks on Prince Edward Island, Canada, with reference to enteric bacteria and antibiotic resistance. Comparative immunology, microbiology and infectious diseases. 2005. v. 28, n. 1, p. 71-82. https://doi.org/10.101/j.cimid.2004.08.001

51. Gibbs PS, Kasa R, Newbrey JL, Petermann SR, Wooley RE, Vinson HM, Reed W. Identification, antimicrobial resistance profiles, and virulence of members from the family Enterobacteriaceae from the feces of yellow-headed blackbirds (Xanthocephalus xanthocephalus) in North Dakota. Avian diseases. 2007. v. 51, n. 3, p. 649-655. https://doi.org/10.1637/0005-2086(2007)51[649:IARPAV]2.0.CO;2

52. Segado-Arenas A, Alonso-Ojembarrena A, Lubián-López SP, García-Tapia AM. Pantoea agglomerans: $¿$ un nuevo patógeno en la unidad de cuidados intensivos neonatales?: a new pathogen at the neonatal intensive care unit?. Archivos argentinos de pediatría. 2012. v. 110, n. 4, p. e77-e79. http://dx.doi.org/10.5546/aap.2012.e77

53. Walterson AM, Stavrinides J. Pantoea: insights into a highly versatile and diverse genus within the Enterobacteriaceae. FEMS microbiology reviews. 2015. v. 39, n. 6, p. 968-984. https://doi.org/10.1093/femsre/fuv027

54. Ewers CATS, Bethe A, Semmler T, Guenther S, Wieler LH. Extended-spectrum $\beta$ lactamase-producing and AmpC-producing Escherichia coli from livestock and companion animals, and their putative impact on public health: a global perspective. Clinical Microbiology and Infection. 2012. v. 18, n. 7, p. 646-655. https://doi.org/10.1111/j.1469-0691.2012.03850.x

55. Riley LW. Pandemic lineages of extraintestinal pathogenic Escherichia coli. Clinical Microbiology and Infection. 2014. v. 20, n. 5, p. 380-390. https://doi.org/10.1111/1469-0691.12646

56. Saviolli JY. Pesquisa e Caracterização de Escherichia coli patogênica (E. coli produtora de toxina Shiga-STEC; E. coli aviária patogênica-APEC) de fragatas (Fregata magnificens) da Costa do Estado de São Paulo. 2010. Tese de Doutorado. Universidade de São Paulo. Disponivel em: https://www.teses.usp.br/teses/disponiveis/10/10133/tde-10082010-143759/en.php 
57. Vilela SM, Pinheiro Júnior JW, Silva JS, Pace FD, Silveira WD, Saukas TN, Mota RA. Research of Salmonella spp. and evaluation of pathogenicity, cytotoxicity of Escherichia coli isolates proceeding from sparrows (Passer domesticus). Pesquisa Veterinária Brasileira. 2012. v. 32, p. 931-935. https://doi.org/10.1590/S0100$\underline{736 \times 2012000900019}$

58. Callaway TR, Edrington TS, Nisbet DJ. Isolation of Escherichia coli O157: H7 and Salmonella from migratory brown-headed cowbirds (Molothrus ater), common grackles (Quiscalus quiscula), and cattle egrets (Bubulcus ibis). Foodborne pathogens and disease. 2014. v. 11, n. 10, p. 791-794. https://doi.org/10.1089/fpd.2014.1800

59. Menezes EA, Cezafar FC, Andrade MDSDS, Rocha MVADP, Cunha FA. Freqüência de Serratia sp em Infecções Urinárias de pacientes internados na Santa Casa de Misericórdia em Fortaleza. Revista da Sociedade Brasileira de Medicina Tropical. 2004. v. 37, n. 1, p. 70-71. https://doi.org/10.1590/S003786822004000100020

60. Fudge AM. Diagnosis and treatment of avian bacterial diseases. Sem. Avian Exotic Pet Medicine. 2001. 10:3-11.

61. Guimarães MB. Passeriformes (pássaro, canário, saíra, gralha). CUBAS, ZS; SILVA, JCR; CATÃO-DIAS, JL Tratado de animais selvagens. São Paulo. 2006. Roca, p. 324-337.

62. Spena MT, Foti M, Fisichella V, Mascetti A, Zafarana MA, Colnaghi M, Grasso R. Physiological and potentially pathogenic microbial flora in stone curlew (Burhinus oedicnemus), southeastern Sicily. Journal of Wildlife and Biodiversity. 2020. v. 4, n. 3, p. 24-36. https://dx.doi.org/10.22120/jwb.2020.128364.1148

63. Wiśniewska H, Niewolak S, Korzeniewska E, Filipkowska Z. Enterobacteriaceae family bacteria in a mesotrophic lake (lake Długie Wigierskie) in the presence of black cormorants (Phalacrocorax carbo). Pol J Nat Sci. 2007. v. 22, p. 486-499. http://dx.doi.org/10.2478/v10020-007-0043-2

64. Albert MJ, Faruque SM, Ansaruzzaman M, Islam MM, Haider K, Alam K, RobinsBrowne R. Sharing of virulence-associated properties at the phenotypic and genetic levels between enteropathogenic Escherichia coli and Hafnia alvei. Journal of Medical Microbiology. 1992. v. 37, n. 5, p. 310-314. https://doi.org/10.1099/00222615-37-5-310

65. Real F, Fernández ACOSTA, Acosta F, Acosta B, Castro P, Déniz S, Orós J. Septicemia associated with Hafnia alvei in laying hens. Avian diseases. 1997. p. 741-747. https://doi.org/10.2307/1592170

66. Miniero Davies Y, Xavier de Oliveira MG, Paulo Vieira Cunha M, Soares Franco L, Pulecio Santos SL, Zanolli Moreno L, Knöbl T. Edwardsiella tarda outbreak 
affecting fishes and aquatic birds in Brazil. Veterinary Quarterly. 2018. v. 38, n. 1, p. 99-105. https://doi.org/10.1080/01652176.2018.1540070

67. Davies YM, Cunha MPV, Oliveira MGX, Oliveira MCV, Philadelpho N, Romero DC, Knöbl T. Virulence and antimicrobial resistance of Klebsiella pneumoniae isolated from passerine and psittacine birds. Avian Pathology. 2016. v. 45, n. 2, p. 194-201. https://doi.org/10.1080/03079457.2016.1142066

68. Asma-Abd-Ellatif M. Studies on enterobacteriaceae in chicken egg. 2013. MVSc, In Poultry Diseases Beni-Suef University

69. Godoy SN, Cubas ZS. Principais doenças bacterianas e fúngicas em Psittaciformes revisão. Clínica Veterinária. 2009. v.14, n.81, p.88-98.

70. Williams JE, Dillard LH. Penetration of chicken egg shells by members of the Arizona group. Avian diseases. 1968 . v. 12, n. 4, p. 645649.https://doi.org/10.2307/1588448

71. Windingstad RM, Trainer DO, Duncan R. Salmonella enteritidis and Arizona hinshawii isolated from wild sandhill cranes. Avian diseases. 1977. p. 704-707. https://doi.org/10.2307/1589429

72. Sato G, Adler HE. Experimental infection of adult turkeys with Arizona group organisms. Avian Diseases. 1966. v. 10, n. 3, p. 329-336. https://doi.org/10.2307/1588279

73. Machado DN, Lopes ES, Albuquerque ÁH, Bezerra WGA, Horn RV, Lima SVG, Teixeira RSC. Detecção e avaliação do perfil de sensibilidade antimicrobiana de enterobactérias isoladas de periquitos cara-suja (Pyrrhura griseipectus) em cativeiro. Arquivo Brasileiro de Medicina Veterinária e Zootecnia. 2016. v. 68, p. 1732-1736. https://doi.org/10.1590/1678-4162-8819

74. Gaio FC, Lopes ES, Lima BP, Carmo CC, Marques AR, Oliveira FR, Maciel WC. Bactérias zoonóticas isoladas de Passeriformes silvestres recuperados do tráfico de animais no estado do Ceará/Brasil. Arquivo Brasileiro de Medicina Veterinária e Zootecnia. 2019. v. 71, p. 1488-1496. https://doi.org/10.1590/1678-4162-10092

75. Carreira AS. AVALIAÇÃO DA MICROBIOTA ENTÉRICA BACTERIANA DEAVES DE VIDA LIVRE CAPTURADAS NO CAMPUS DO ITAPERI DA UNIVERSIDADE ESTADUAL DO CEARÁ, FORTALEZA-CE. 2019. $72 \mathrm{f}$. Dissertação (Mestrado) - Curso de Programa de Pós-graduação em ciências Veterinárias, Universidade Estadual do Ceará, Fortaleza - Ceará. Disponível em: $<$ http://www.uece.br/ppgcvwp/wpcontent/uploads/sites/6/2019/08/ArianneCarreira Disserta\%C3\%A7\%C3\%A3o.pdf>. Acesso em: 06 jan. 2020.

76. Tsubokura M, Matsumoto A, Otsuki K, Animas SB, SanekataT. Drug resistance and conjugative $\mathrm{R}$ plasmids in Escherichia coli strains isolated from migratory waterfowl. Journal of wildlife diseases. 1995 v. 31, n. 3, p. 352-357. https://doi.org/10.7589/0090-3558-31.3.352 
77. Carter DL, Docherty KM, Gill SA, Baker K, Teachout J, Vonhof MJ. Antibiotic resistant bacteria are widespread in songbirds across rural and urban environments. Science of the Total Environment. 2018. v. 627, p. 1234-1241. https://doi.org/10.1016/j.scitotenv.2018.01.343

78. Shobrak MY, Abo-Amer AE. Role of wild birds as carriers of multi-drug resistant Escherichia coli and Escherichia vulneris. Brazilian Journal of Microbiology. 2014. v. 45, p. 1199-1209. https://dx.doi.org/10.1590\%2Fs1517-83822014000400010

79. Giacopello C, Foti M, Mascetti A, Grosso F, Ricciardi D, Fisichella V, Piccolo FL. Antimicrobial resistance patterns of Enterobacteriaceaein European wild bird species admitted in a wildlife rescue centre. Vet. Ital. 2016. v. 52, p. 139-144. doi: 10.12834/VetIt.327.1374.2

80. Ramey AM, Hernandez J, Tyrlöv V, Uher-Koch BD, Schmutz JA, Atterby C, Bonnedahl J. Antibiotic-resistant Escherichia coli in migratory birds inhabiting remote Alaska. EcoHealth. 2018. v. 15, n. 1, p. 72-81. doi: 10.1007/s10393-017$1302-5$

81. Tormoehlen K, Johnson-Walker YJ, Lankau EW, San Myint M, Herrmann JA. Considerations for studying transmission of antimicrobial resistant enteric bacteria between wild birds and the environment on intensive dairy and beef cattle operations. PeerJ. 2019. v. 7, p. e6460. doi:10.7717/peerj.6460

82. Iroha I, Afiukwa F, Oji A, Ejikeugwu P, Nwakeze E. Occurrence of extended spectrum beta lactamase producing Escherichia coli from human clinical and wild birds (pigeons, bats, parrots and ducks) samples from Ebonyi state, Nigeria. World J. Pharm. Sci. 2015. v. 4, p. 20-29.

83. Sousa ATHI, Makino H, Bruno VCM, Candido SL, Nogueira BS, Menezes IG, Dutra V. Perfil de resistência antimicrobiana de Klebsiella pneumoniae isoladas de animais domésticos e silvestres. Arquivo Brasileiro de Medicina Veterinária e Zootecnia. 2019. v. 71, p. 584-593. https://doi.org/10.1590/1678-4162-10599

84. Ong KH, Khor WC, Quek JY, Low ZX, Arivalan S, Humaidi M, Aung KT. Occurrence and antimicrobial resistance traits of Escherichia coli from wild birds and rodents in Singapore. International Journal of Environmental Research and Public Health. 2020. v. 17, n. 15, p. 5606. https://doi.org/10.3390/ijerph17155606

85. Foti M, Grasso R, Fisichella V, Mascetti A, Zafarana MA, Colnaghi M, Spena MT. Analysis of Eurasian Stone curlew (Burhinus oedicnemus) microbial flora reveals the presence of multi-drug resistant pathogens in agro-pastoral areas of Sicily (Italy). Heliyon. 2020. v. 6, n. $10, \quad$ p. e05401. https://doi.org/10.1016/j.heliyon.2020.e05401

86. Khan MU, Yousuf RI, Shoaib MH. Drug utilization evaluation of meropenem and correlation of side effects with renal status of patients in a teaching based hospital. Pak J Pharm Sci. 2014. v. 27, n. 5, p. 1503-8. PMID: 25176244. 
87. Blumentrath CG, Müller G, Teichmann D, Tiesmeier J, Petridou J. Relapse of typhoid fever following delayed response to meropenem: a case report and review of previously published cases indicating limited clinical efficacy of meropenem for the treatment of typhoid fever. GMS German Medical Science. 2019. v. 17. doi: $10.3205 / 000267$

88. De Camargo TV, da Silva Junior JM, Junior ÉMS, Santos VJ, Rocha A, Lanchote VL, de Souza Gomez D. Abordagem farmacocinética-farmacodinâmica (PK/PD) na avaliação da efetividade do Meropenem em pacientes sépticos queimados adolescentes versus adultos jovens/PK/PD approach to evaluate Meropenem effectiveness in critically ill burn adolescents versus young adults undergoing therapy of septic shock. Brazilian Journal of Health Review. 2021. v. 4, n. 1, p. 1213-1232. doi:10.34119/bjhrv4n1-107

89. Guerra B, Fischer J, Helmuth R. An emerging public health problem: acquired carbapenemase-producing microorganisms are present in food-producing animals, their environment, companion animals and wild birds. Veterinary microbiology. 2014. v. 171, n. 3-4, p. 290-297. https://doi.org/10.1016/j.vetmic.2014.02.001

90. Nascimento AM, Cursino L, Gonçalves-Dornelas H, Reis A, Chartone-Souza E, Marini MÂ. Antibiotic-resistant Gram-negative bacteria in birds from the Brazilian Atlantic forest. The Condor. 2003. v. 105, n. 2, p. 358-361. https://doi.org/10.1093/condor/105.2.358

91. Ledeberg J. Infectious disease as an evolutionary paradigm. Emerging infectious diseases. 1997. v. 3, n. 4, p. 417. doi: 10.3201/eid0304.970402

92. Singer RS, Ward MP, Maldonado G. Erratum: Can landscape ecology untangle the complexity of antibiotic resistance?. Nature Reviews Microbiology. 2007. v. 5, n. 1, p. 82-82. https://doi.org/10.1038/nrmicro1593

93. Gottdenker NL, Walsh T, Vargas H, Merkel J, Jiménez GU, Miller RE, Parker PG. Assessing the risks of introduced chickens and their pathogens to native birds in the Galápagos Archipelago. Biological Conservation. 2005. v. 126, n. 3, p. 429-439. https://doi.org/10.1016/j.biocon.2005.06.025

94. Pallecchi L, Lucchetti C, Bartoloni A, Bartalesi F, Mantella A, Gamboa H, Rossolini GM. Population structure and resistance genes in antibiotic-resistant bacteria from a remote community with minimal antibiotic exposure. Antimicrobial agents and chemotherapy. 2007. v. 51, n. 4, p. 1179-1184. doi: https://doi.org/10.1128/AAC.01101-06

95. Bartoloni A, Pallecchi L, Rodríguez H, Fernandez C, Mantella A, Bartalesi F, Rossolini GM. Antibiotic resistance in a very remote Amazonas community. International journal of antimicrobial agents. 2009. v. 33, n. 2, p. 125-129. https://doi.org/10.1016/j.ijantimicag.2008.07.029 
96. Portugal DSG. Prevalência de bactérias resistentes a antimicrobianos em água natural. 2015. 84 f. Dissertação (Mestrado). Mestrado Integrado em Engenharia Química. Faculdade de Engenharia. Universidade do Porto.

97. Hernández J, González-Acuña D. Anthropogenic antibiotic resistance genes mobilization to the polar regions. Infection ecology \& epidemiology. 2016. v. 6, n. 1, p. 32112. https://doi.org/10.3402/iee.v6.32112

98. Salyers AA, Amabile-Cuevas CF. Why are antibiotic resistance genes so resistant to elimination?. Antimicrobial agents and chemotherapy. 1997. v. 41, n. 11, p. 23212325. https://doi.org/10.1128/AAC.41.11.2321. PMID: 9371327

99. Brinkmeyer R, Knittel K, Jürgens J, Weyland H, Amann R, Helmke E. Diversity and structure of bacterial communities in Arctic versus Antarctic pack ice. Applied and environmental microbiology. 2003. v. 69, n. 11, p. 6610-6619. https://doi.org/10.1128/AEM.69.11.6610-6619.2003

100. Benskin CMH, Wilson K, Jones K, Hartley IR. Bacterial pathogens in wild birds: a review of the frequency and effects of infection. Biological Reviews. 2009. v. 84, n. 3, p. 349-373. doi:10.1111/j.1469-185x.2008.00076.x

101. Bonnedahl J, Järhult JD. Antibiotic resistance in wild birds. Upsala journal of medical sciences. 2014. v. 119, n. 2, p. 113-116. https://doi.org/10.3109/03009734.2014.905663

102. Allen HK, Donato J, Wang HH, Cloud-Hansen KA, Davies J, Handelsman J. Call of the wild: antibiotic resistance genes in natural environments. Nature Reviews Microbiology. 2010. v. 8, n. 4, p. 251-259. doi:10.1038/nrmicro2312

103. Martinez JL. The role of natural environments in the evolution of resistance traits in pathogenic bacteria. Proceedings of the Royal Society B: Biological Sciences. 2009. v. 276, n. 1667, p. 2521-2530. https://doi.org/10.1098/rspb.2009.0320 